\title{
ПРОБЛЕМИ И ИЗАЗОВИ У РЕАЛИЗАЦИЈИ НАСТАВЕ СРПСКОГ КАО ЈЕЗИКА ОКРУЖЕЫА И ОБРАЗОВАЊА У ШКОЛАМА НА ПОДРУЧЈУ ЈУГОИСТОЧНЕ СРБИЈЕ
}

\begin{abstract}
Актуелна демографска кретања у свету и код нас имају свој рефлекс и на образовне токове у Србији, а посебно се актуелизују изазови у настави српског језика. У низу значајних промена, најупечатљивија је она која се тиче интегрисања деце миграната у наш школски систем и то пре свега у основне и средње школе у местима у чијој околини се налазе прихватилишта за мигранте. Оваква новонастала ситуација представља велики изазов за учитеље и наставнике српског језика који нису на иницијалном нивоу образовања обучени за извођење наставе српског као страног. Додатна проблемска ситуација у настави настаје убацивањем ученика азиланата у већ постојећа одељења и њихово укључивање у текуће наставне процесе чиме се настава поставља на ниво рада у комбинованом одељењу. Министарство просвете, науке и технолошког развоја Републике Србије, Уницеф, Група за децу и младе „Индиго” и високообразовне институције у Србији учинили су напоре да помогну наставницима српског језика у превазилажењу овог проблема организацијом стручних семинара, мониторингом и пружањем консултативне стручне помоћи у настави српског као језика окружења и образовања. У раду се анализира дидактички оквир наставне реализације српског као језика окружења и образовања, указује се на ставове и мишљења учитеља и наставника српског језика о раду са ученицима азилантима и изводе се закључци у вези са унапређењем наставне праксе ове нове лингвометодичке дисциплине.
\end{abstract}

Кључне речи: настава српског језика, српски као страни, српски као језик окружења и образовања.

\footnotetext{
${ }^{1}$ marina.janjic@filfak.ni.ac.rs

2 Рад је настао у оквиру пројеката: „Динамика структура српског језика”, пројекат Министарства науке Републике Србије, бр. 178014; и „Српски језик некад и сад: лингвистичка истраживања", који се реализује на Филозофском факултету у Нишу бр: 360/1-16-10-01.
} 


\section{Увод}

У оквиру пројекта подршке наставницима који реализују наставу српског као језика окружења и образовања са ученицима азилантима, у суорганизацији: Министарства просвете, науке и технолошког развоја Републике Србије, УНИЦЕФ ${ }^{3}$-а, Групе за децу и младе „Индиго” и Филозофског факултета у Нишу, на пролеће 2018. године организована је посета школама у пограничним општинама источне и јужне Србије ${ }^{4}$ које похађају ученици мигранти тражиоци азила. Ова посета представљала је у извесном смислу мониторинг

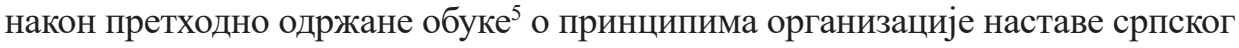
као језика окружења и образовања. Овога пута, подршка супервизијског тима подразумевала је посету школама и одељењима са мигрантским учесницима и опсервацију наставе српског језика према предвиђеном протоколу заснованом на принципима нове лингвометодичке дисциплине: методике наставе српског као језика окружења и образовања. Након завршеног часа, следио је појединачни разговор са учитељима и наставницима српског језика о начину рада са азилантским ученицима, да би на крају радног дана био организован састанак рефлексије са свим наставницима из града који у својим одељењима имају мигрантске ученике у циљу превазилажења практичних проблема у раду са мигрантском децом. Настава српског као језика окружења и образовања представља нов начин рада и велики изазов за актуелне наставнике у креирању и извођењу наставног процеса. Језичка баријера и културолошке разлике представљају значајне моменте са којима се наставници морају суочити и превазићи их. Како би им олакшали ове задатке теоретским и практичним решењима, тимови подршке 6 кренули су у сусрет овим изазовима. Врхунац посете школама представљао је управо састанак рефлексије са свим наставницима из тог места на коме се отварала жива дискусија о изазовима, проблемима, предлозима за њихово решавање и примерима добре праксе. Такође, ове посете биле су и мотивационог карактера у охрабривању наставника да буду истрајни у помоћи деци азилантима и олакшају њихово укључивање у образовни систем у миграционим условима.

\footnotetext{
${ }^{3}$ Међународни дечји фонд Уједињених нација који се брине о квалитету њиховог животног стандарда.

${ }^{4}$ У питању су општине: Пирот, Бела Паланка, Димитровград, Врање, Бујановац и Прешево.

${ }^{5}$ У организацији Министарства просвете РС, Центра за образовне политике, УНИЦЕФ-а и Индига организована је обука под називом: Подршка наставнищима српског језика у реализачији наставе српског језика за ученике мигранте. Обука је реализована два пута по два дана и то: у Пироту 7. и 8. 12. 2017. и Нишу 21. и 22. 12. 2017. Водитељ обука био је аутор овог текста.

${ }^{6}$ Тимове подршке на подручју читаве Србије чинили су представници универзитета (међу којима и сам аутор), наставници практичари са искуством у раду са ученицима избеглицама/ мигрантима, као и представници Министарства просвете, школских управа, Уницефа и Групе за децу и младе „Индиго”.
} 


\section{1. Методологија наставног рада}

Методика наставе српског као језика окружења и образовања представља најмлађу грану лингвометодике, у класи наставе српског као страног језика. Она је настала као резултат учесталих миграционих кретања, односно пораста броја и/миграната који се у дужем временском периоду задржавају у нашој земљи. Такође, повећава се и број пословних људи из иностранства који са својом породицом проводе један животни период у нашој земљи. Према Уставу Републике Србије (2006) деца страних држављана имају право на бесплатно школовање у нашој земљи, што се детаљно експлицира и у Закону о основама система образовања и васпитања (Члан 6).

У току прошле школске године учитељи и наставници српског језика у основним и средњим школама ухватили су се у коштац са не баш тако једноставним професионалним изазовом, а то је интеграција азилантских ученика у редовне наставне токове са превасходним задатком усвајања српског језика као страног. И поред тога што су учествовали на стручном семинару обуке за рад са ученицима азилантима, ова методологија рада се јако разликује од наставе матерњег језика (што је њихова примарна професионална оријентација) за шта су едуковани на иницијалном нивоу студија и чиме су се бавили током своје просветне делатности.

Оквир програма језичке подршке - методички приручник намењен наставницима српског језика у раду са ученицима азилантима представља тимски рад професора Филолошког факултета у Београду нили оперативни садржај обуке увођењем у најважније постулате наставе српског као страног у правцу модификације ка посебностима рада са азилантским ученицима. Најважније карактеристике овог програма обуке јесу: учење српског као страног усмерено на исходе и компетенције, доминација комуникативне методе, интеркултуралност и трансјезичност. У фокусу наставног рада јесте развој језичких вештина: слушање и разумевање, читање, писање и говорење, као и упознавање са граматичким садржајем. Будући да је овде реч о интеграцији ученика азиланата у наставни процес регуларне наставе српског језика и књижевности, указало се на начин рада у комбинованом одељењу. Оваква наставна интеграција заснована је на креирању разноврсних ситуација учења за азилантске ученике који су се, онолико колико то дозвољава њихово познавање српског језика, макар и делимично укључивали у садржај наставног рада са нашом децом. Те ситуације учења представљају прави методички маневар и највећи изазов за учитеље и наставнике. Најпре, овакав методички подухват у својој основи заснован је на Заједничком европском оквиру за живе језике (2003) према модулима

\footnotetext{
Проф. др Јулијана Вучо, доц. др Љиљана Ђурић, проф. др Весна Крајишник, мср Никица Стрижак, мср Мина Сукновић, проф. др Јелена Филиповић потписују методички приручник: „Од српског као страног језика до српског као језика окружења и образовања: Оквир програма језичке подршке” (Београд 2018).
} 
(најнижи ниво - модул 1, средњи ниво - модул 2 и и виши ниво - модул $3)^{8}$ у којима су наведене: теме и животне ситуације које могу представљати наставни садржај ситуације учења (лично представљање, време, здравље, образовање, куповина...); затим, даје се препорука метода и активности које могу бити примењене у ситуацијама учења, ако и комуникативне функције које треба развити (постављање и одговарање на питања, молбе и изрази захвалности, именовање боја, бројање до 100...). На основу овакве матрице, учитељ/наставник српског језика креира сиутације учења за мигрантске ученике настојећи да их макар и парцијално укључи у редовне наставне токове са осталим ученицима. У извођењу наставе српског за азилантске ученике, посебно је наставницима драгоцена примена индивидуализоване наставе у више нивоа сложености, тако да се наставни садржај диференцира на наставу српског као матерњег за постојеће одељење и наставу српског као страног (тј. српског као језика образовања и окружења) за ученике азиланте тако да се њима дају задаци сходно нивоу њиховог познавања српског језика и прилагођени њиховим потребама и посебностима.

Посебно треба истаћи врлине КЛИЛ методе - тј. начина интегрисаног учења српског језика уз садржаје других наставних предмета. „Када је у питању настава српског као страног језика за децу и одрасле тражиоце азила свакако не смемо заборавити опште принципе добре наставе: интегративност, интердисциплинарности, прилагођеност узрасту, индивидуалним потребама ученика, као и потребама заједнице у којој живе" (ВУЧО И САР. 2018: 18). Посебности КЛИЛ ${ }^{9}$ наставе (интегрисано учење језика и садржаја) која постоје незаобилазна у настави Ј2 у свету, а сада и код нас, леже у спајању четири међузависна процеса: садржај, когницију, културу и комуникацију у циљу учења страног језика. Другим речима, изучавајући садржаје из различитих културолошких тема других наставних предмета, наставник их комбинује са дидактичким поступцима карактеристичним за наставу страног језика (маркирање и учење непознатих речи, превођење, разумевање прочитаног, преписивање, запамћивање, разговор о тексту...).

Дакле, настава српског језика као страног (тј. језика окружења и образовања) базирана је на чињеници да ученици азиланти не могу за тако кратак временски рок достићи ниво језичке компетенције једнак изворном говорнику српског језика па се акценат ставља на комуникацију и преношењу информација, а не на граматичку коректност и доследност (значи, може се грешити, али је важно да је информација разумљива). Будући да је њихово познавање српског на ниском нивоу, а да многи од њих, поред матерњег, владају и енглеским језиком, у учионици се може успоставити и трансјезична комуникација, тј. дозвољава се употреба свих језичких средстава у току

\footnotetext{
${ }_{8}^{8}$ Модул 1 је намењен узрасној групи од 6 до 10 година; модул 2 ја намењен узрасту од 10 до 15 година и модул 3 је намењен полазницима старијим од 15 година.

${ }^{9} \mathrm{CLIL}=$ Content and Language Integrated Learning
} 
говорног чина ради остваривања комуникације (тј. у реченицу на српском језику може се убацити и по нека енглеска или реч на фарсију). Тако долази до прекључивања кода, тј. преплитања више језика у саставу једне реченице. Трансјезичност је карактеристика наставе српског као језика образовања и окружења искључиво на почетном нивоу усвајања српског језика.

Интеркултуралност подразумева неговање различитих култура на часу, тј. теме из културне баштине земље из које потичу азилантски ученици могу бити повезане и упоређене са темама из српске културне баштине. На овај начин, екстралингвистички фактори представљају значајан тематски оквир наставног контекста што наставу чини подстицајном и занимљивом и за домаће и за азилантске ученике јер је то прилика да се чују занимљиве појединости о националној културној баштини и једних и других. Интеркултуралност даје могућности додатног подстицаја за рад и појачане мотивације за ученике, а за ученике мигранте представља додатно емоционално охрабрење и алтруистички доживаљај средине у којој су смештени. Овим се повезују когнитивна и афективна страна учења јер: „Како Стивен Крашен тврди, усвајање језика је најефикасније ако је 'афективни филтер' низак. Тако је и усвајање језика најпродуктивније у оној средини где нема стреса и немира, осуде и подсмеха. [...] На наставницима је да кроз интеркултуралне компетенције и хуманистички приступ настави, као и културно осетљиве материјале, обезбеди снижавање афективног филтера" (ВУЧО И САР. 2018 : 14). Ово је утолико важније уколико знамо да је реч о деци која долазе из ратне средине и која су на миграционом путу доживела разне трауме и трагедије те је њима људска подршка најпотребнија. На часовима српског језика као страног, стога је неопходно обезбедити им инклузију уз осећања емпатије и саосећања за животним удесом који их је задесио.

Осим неговања и респектовања културолошких и социјалних разлика, наставници могу ситуације учења српског језика као страног утемељити на њиховим индивидуалним посебностима, талентима и преференцијама (спорт, музика, игра, уметност...). Они могу своје домете и врлине поделити са домаћим ученицима, али може бити и драгоцена интеграција њихових родитеља и сродника у светковању каквих празника, изради уметничких или прикладних предмета (новогодишње честитке, корпице, икебане или какви други предмети из области народне радиности).

Комуникативна и интеркултурна настава захтевају комуникативну активност ученика азиланата на часу и усвајање српског језика учествовањем у говорним чиновима који се инсценирају током наставног процеса. Партиципацијом на часу „из туђих ципела“, тј. играњем улога, имагинативним активностима којима се говорне активности чине занимљивијим и разноврснијим, настава српског као језика окружења излази из оквира сувопарног граматизирања и доноси ученицима позитиван доживљај српског као страног језика. Креирањем игровних и имагинативних ситуација учења наста- 
ва српског језика за ученике азиланте реализује се у форми инвентивних и подстицајних језичких радионица.

На крају, за евалуацију постигнућа ученика препоручује се употреба европског језичког портфолија ${ }^{10}$ који представља лични документ curriculum linguae сваког ученика азиланта и у коме се налазе подаци о знању коју поседују у одређеном тренутку; затим, о дипломама и сертификатима које поседује; ту је и језичка биографија и досије (подаци о претходном раду ученика и академским активностима), као и све остале појединости везане за формално и неформално образовање.

\section{2. Анализа и стручна опсервација посећених часова српског као језика окружења и образовања}

Стање у школама указује на то да је већина ученика азиланата напредовала у савладавању српског језика од почетка школске године до тренутка супервизије. За релативно кратко време (у току зимског полугодишта) добар део ученика миграната је овладао једним одабраним фондом српских речи, тако да су били у могућности да са разумевањем прате налоге својих наставника, одговарају на њихова питања, а релативно брзо напредују у читању и писању српских графема. Сви наставници су посебно нагласили да им је веома значио претходно одржани семинар у Нишу и Пироту (организован у децембру 2017. године) и да све савете које су тамо усвојили примењују у свом раду.

\section{1. Проблеми у реализацији наставе српског као језика} окружења и образовања

Постоји велики број проблема објективне природе који представљају огроман камен спотицања у реализацији овог наставног рада. Првенствено, са професионалног аспкета, велики проблем чини недостатак стручне литературе и уџбеника српског језика намењених мигрантским ученицима. Српски као језик окружења и образовања мигрантским ученицима представља страни језик са којим се они по први пут сусрећу и стога би од огромне користи и наставницима и ученицима били специјализовани уџбеници, радне свеске и пратећа опрема (озвучени буквар или звучне читанке) којима би наставни рад био не само олакшан, већ би постигнућа ученика у савладавању српског језика била неоспорно бржа и ефективнија. Такође, ту су и технички проблеми који се тичу школске администрације, тј. евидентирања

${ }^{10}$ „Европски језички портфолио нуди како рангирање општих компетенција на већем броју језика, тако и класификацију језичких функција која нуди верну слику циљева и исхода у складу са различитим потребама, карактеристикама и могућностима ученика" (ВУЧО И CAP. 2018: 107). 
ученика азиланата у школским књигама, оцењивање и вредновање њиховог постигнућа, планирање и програмирање градива намењеног овим ученицима према узрасту, комбиновање рада са постојећим одељењем и ученицима азилантима, али и издавања потврда о школовању у српским школама. Једном речи, њихов статус ваљало би решити формално и административно на законски регулативан начин. Чињеница је да наставници нису темељно обучени за рад са ученицима из иностранства (који не знају српски језик), тј. нису квалификовани да изводе наставу српског као страног која се у многоме разликује од наставе српског као матерњег.

На основу свега овога јасно је да су се нужно јавиле потешкоће у наставном раду како са аспекта учитеља и наставника српског језика тако и са аспекта ученика азиланата. Њима је ипак најтеже, обрели су се у непознатој средини након ратних и миграционих траума у тренутку неизвесности властите егзистенције. Време боравка у прихватилиштима је непознаница те многи ученици после два-три месеца напусте прихватилиште, а код неких је период боравка на нашој територији и знатно дужи. Дакле, време боравка миграната у прихватилиштима у Србији и похађања наставе је неизвесно и неуједначено што омета континуитет у настави српског као страног.

При том, актуелни проблеми везани за мигрантске ученике су психолошке, социолошке и културолошке природе. Има много индивиуалних разлика међу ученицима мигрантима (у истом одељењу) зависно од узраста, пола и порекла, па им се разликују матерњи језици као и традиционалне и културолошке вредности. Присуство више ученика миграната различитог порекла у учионици може посебно закомпликовати ситуацију. Међу њима има и оних који не желе да уче српски језик, нису заинтересовани ни мотивисани да прате активности и налоге на часу или их у томе спутавају негативни ставови њихових родитеља. Све су ово реални проблеми са којима су суочени учитељи и наставници српског језика у школама са мигрантским ученицима.

\subsection{1. Проблеми организационе природе}

Почетак извођења наставе је био посебно тежак за наставнике из више разлога: поред већ поменутих објективних и професионалних разлога (нема уџбеника ни приручника, није био познат формални статус ученика миграната, није се знало ни шта ће бити са децом азилантима која остану до краја школске године, тј. да ли ће бити уведена у дневник, матичну књигу, да ли ће имати ђачку књижицу...), било је и субјективних негативних реакција наиме, поједини наставници су имали отпор према ученицима мигрантима због повећаног обима посла, а јавиле су се и предрасуде о самим азилантима. Такође, негативна је била рекација и самих житеља (посебно родитеља наших ученика) да прихвате децу азиланте, што је додатно погоршавало стање. 
Ипак, највећи пробем у настави са ученицима мигрантима наставницима српског језика представљало је повезивање редовних наставних садржаја и наставе српског као страног при чему су још увек били недефинисани стандарди, као и очекивани исходи и компетенције ове наставе. Било је тешко успоставити везу између редовног планираног градива и оног што би требало да уче мигранти. Највећа бојазан код наставника српског језика била је недостатак методичких компетенција и неискуство у извођењу наставе српског као страног ${ }^{11}$ па се инсистирало на сарадњи са наставницима страног језика (енглеског, француског, руског...) који би им указивали на дидактичку обликованост ових часова и на примену адекватних методичких радњи у настави страног језика. Такође, помагали су им и волонтери и преводиоци са језика азиланата: пашту (авганистански) и фарси (персијски), урду, дари. Наставници су били прави виртуози на својим часовима користећи се креативношћу у осмишљавању ситуација учења за азилатнске ученике. Јавиле су се потешкоће у томе што је азилантским ученицима често била потребнија већа и неподељена пажња око израде задатака. Овај проблем је био решаван принципима рада у комбинованом одељењу, тј. подељеним активностима: док домаћи ученици самостално или у групи раде на решавању истраживачких задатака, наставник је водио дијалог са азилантским ученицима и обрнуто. Такође, неопходно је укључити азилантске ученике у рад са осталим ученицима како не би били запостављени и маргинализовани на часу. Мора се водити рачуна да увек буду ангажовани и активни у току часа.

За релативно кратко време предрасуде и стереотипи су били успешно превладани. Показало се да су страхови били неосновани јер се показало да су ученици азиланти уредни, педантни, одговорни, а њихово понашање културно. Локални ученици су претходно припремљени за њихов пријем и створена је подстицајна атмосфера у одељењу за толеранцију и хумани приступ према страдалничкој ситуацији ученика из ратом захваћених подручја. Показале су се позитивне реакције на различитост у култури, географским и осталим околностима. Генерално посматрано, рад са децом азилантима и сарадња са њиховим родитељима у школама на подручју југоисточне Србије одвијају се без проблема. Језик пријатељства и хумани простор у школи доприносе да се деца мигранти осећају лепо у школи и да се друже с другарима.

На часовима се непрестано ради на повезивању њихове културе са нашом. Тај јаз је превазиђен разним игровним и радионичарским активностима поводом новогодишњих празника, прославе Божића, Ускрса, Дана матерњег језика, Дана жена, Дана мајки, као и њихових важних верских и других догађаја. Језичка спона успостављена је и на плану израде ликовних радова, организацији спортских такмичења, културно-уметничког програ-

\footnotetext{
${ }^{11}$ Општи је закључак да су се у овој новонасталој ситуацији много боље снашли учитељи који су на својим студијским програмима учитељских факултета стекли много више педагошкопсихолошких компетенција. Наставнике српског је збуњивала методолошка различитост између наставе српског као матерњег и српског као страног језика.
} 
ма, на плану гастрономије и свему осталом што њихову културу чини специфичном у односу на нашу.

\section{2. Предлози за унапређење наставе српског као језика окружења и образовања}

На основу дискусије која се развијала на састанцима рефлексије са наставницима српског језика који раде са ученицима азилантима, искристалисало се више практичних предлога за извођење наставе српског као језика окружења и образовања од стране наставника практичара:

- увек кад је то могуће направити компарацију и интеграцију између юихове и наше културе кроз све видове креативних радионица (галеријске и друге поставке, изложбе радова, рукотворине, предмети, књиге, музичко вече, националне игре...);

- применити стрпљивост и обазривост у приступу ученицима мигрантима, водити рачуна о юиховим емоцијама с обзиром на невоље и патье којима су били изложени за време проведено у избеглиштву; показати интересовање за юихову културу;

- обуке за извођење наставе српског као страног/језика окружена и образовања искористити за унапређене редовне формалне наставе јер је иновативна наставна теорија пријемчива и доноси бенефите и у раду са домаћим ученищима; ситуащије учењ а усмерене на (језичке) компетениије новина су која је непозната многим претходним генерачијама наставника;

- применити периферно учење у учионици и у заједничким просторијама школе у виду вишејезичних постера, паноа, плаката ...;

- укључивати ученике мигранте у приредбе и друге јавне активности унутар школе;

- $\quad$ у предворју школа уприличити етно-кутак културе земље из које потичу азилантски ученици; поставити изложбу са експонатима, фотографијама, натписима на њиховом и српском језику, ...;

- н на часу дати прилику ученицима мигрантима да се укључују у наставни оквир износећи детаље из свог претходног школског и животног искуства (нпр. којим данима ви идете у школу, од колико до колико сати сте у школи, како изгледа пролеће код вас, које су вам биле најомиьеније игре ...);

- као добра пракса истиче се и ослањање на трансјезичност; олакшавајућа околност је то што ученици мигранти најчешће знају енглески; једна ученица мигранткиња је претходно научила бугарски језик, ито јој значајно олакиава споразумевање на српском језику;

- важно је дозволити грешке деци азилантима, користити их као прилику за учење, кориговање, акценат је на комуникативној способности креирања исказа на српском језику; 
- $\quad$ за учење српског језика користити све расположиве ресурсе из реалног жсиота (огласне табле, ред вожне на аутобуским станицама, ценовнике, јавна обавештена, рекламе, програм биоскопског репертоара, мени у ресторану....);

- двојезичне и тројезичне радионице су добар пример праксе: наставници и вршњачки едукатори (у улози културних медијатора) обрађују разноразне теме из свакодневног живота (куповина, сналажење у простору...); наставници ученике мигранте стављају у позицију наставника - подучавање других је најмоћнији метод у учењу;

- пример добре праксе је и сарадюа са наставницима из кампа, како би се ускладили наставни садржаји у кампу и у школи.

- трансјезичност у настави: израда паноа за периферно учене на различитим језицима;

- ученици-мигранти укьучени у обележавање Дана матерњег језика; омогућити им учешће на школским фестивалима; организација округлог стола о одрђеној теми, нпр. Драгој особи с љубављу током којег су ученици правили поклоне за 8. март;

- примењивати међупредметно повезивање градива из језика и осталих предмета током припремања часова: на пример, упознавање са релацијским односима као производ повезивана српског језика и ликовног васпитања, те српског језика и математике; препоучује се и израда заједничких пројеката ради појашњавања наставних садржаја;

- неопходно је публиковање стручних радова, тј. сценарија за часове који се могу сматрати угледним, тј. који испуюавају све захтеве везане за успешни развој језичких компетенција код ученика азиланата; најбоље је да се овакви стручни радови објаве у часописима који су читани и доступни већини наставника (Учење и настава, Методичка пракса, Иновачије у настави...); на овај начин биће охрабрени и остали наставници који раде са мигрантима и који могу применити такве функционалне моделе рада на својим часовима;

- направити једну затворену друштвену групу на нету (фејсбуку) која ће повезати све наставнике који раде са ученицима мигрантима у иелој земьи како би се лако могле делити идеје, теме, текстови, линкови, фотографије, искуства, а и решавати текући проблеми током извођена наставе;

Наставници практичари у раду са ученицима мигрантима закључују:

- Постигнућа у области српског као страног зависе од индивидуалних карактеристика самих ученика азиланата, различито напредују као и сва друга дейа. 
- Најбитније је да су ученици мигранти прихваћени, да се у школи осећају сигурно и да и њихови родитељи то знају. Као добра пракса истиче се добра сарадња са родитељима азилантима, као и узајамна помоћ деце миграната у учеюу.

- Деца мигранти су се баш уклопила у средину. Заинтересовани су за рад, захвални су за то што су укьучени у школу, заинтересовани су за образовање, жељни су учења, просто упијају. И овдашња деца и деца мигранти су отворени, спремни да се узајамно разумејy.

- $\quad$ У Гимназији у Димитровграду редовни ученици баве се хуманитарним радом и ван часова и боравка у школи, тако да и кроз те активности пружају подршку ученицима мигрантима.

- Код наставника постоји страх да ће редовни ученици бити запостављени ако се превелика пажња поклања настави српског као језика окружења и образовања и мигрантским ученицима.

- Ученици мигранти обожавају физичко васпитање, ликовну културу. Играју се и у учионици, учили су да играју наша кола, а нашој деци показали су неке своје игре.

- Пратиочи из прихватног центра су били велика подрика азилантима ученицима. Дешава се да нека деца азиланти често изостају из школе од како више нема пратилаца.

- Велики проблем представља нередовност похађања наставе од стране ученика миграната/избеглица. Некада је разлог томе субјективни, а каткад и објективни - лоша организащија превоза деце из кампова.

- Неопхоно је наставницима организовати похађање курса Методика наставе српског језика као страног на Филозофском факултету Универзитета у Нииу.

\section{3. Закључак}

Настава српског као језика окружења и образовања почела је да се реализује у школској 2017/18. години у нашим школама у процесу интеграције ученика азиланата у наш школски систем у основним и средњим школама које се налазе у близини прихватних центара за мигранте. Међу њима су и школе на подручју јужне и источне Србије чији су учитељи и наставници српског језика учествовали на стручним семинарима и обукама за извођење ове наставе како би се прилагодили новим наставним задацима. Подршка њиховом раду настављена је у континуитету од стране Министарства просвете, науке и технолошког развоја и универзитетских професора, Уницефа и Индига како би се превазишли проблеми и потешкоће приликом извођења наставе. 
Осим разуђених дидактичких карактеристика ове лингвометодичке гране, током рефлексија о овој врсти наставе, акценат је био на когнитивној и афектнивној страни учења српског као страног, са посебним освртом на неговање и стицање комуникативних и интеркултурних компетенција код ученика азиланата. Овладавање српским језиком утемељено је на хуманистичком приступу настави, те неговању њене социјалне и културне димензије. Кључни моменат у наставном раду са ученицима азилантима представља креирање ситуација учења српског као језика окружења и образовања, индивидуализованој настави и диференцираним задацима у више нивоа сложености. Посебно је важна примена КЛИЛ методе која подразумева учење српског као страног уз савладавање садржаја из осталих наставних предмета.

Упркос многобројним потешкоћама, настава српског као језика образовања и окружења показала је значајан успех и задовољавајуће резултате у школама на подручју јужне и источне Србије.

\section{Цитирана литература}

COPPEDGE, L. Floyd. „Characteristics of Individualized Instruction”. The Clearing House: A Journal of Educational Strategies, Issues and Ideas, 48(5) (1974): 272-277.

ĐIGIĆ, Gordana. Upravljanje razredom - savremeni pristup psihologiji nastavnika. Niš: Filozofski fakultet, 2017.

HATTIE, John. Visible Learning for Teachers: Maximizing Impact on Learning. London: Routledge, 2012.

HEATHERS, A. Glen. ,Working definition of individualized instruction”. Educational Leadership, February (1977): 342-345.

HOLLENWEGER, Judith. Linking Theory to Practice, UNICEF To Modules on Inclusive Education, Introductory Booklet. New York: UNICEF, 2015.

HOLENVEGER, Džudit, Edina Krompak. Priručnik za nastavnike: aktivnosti za podršku svim učenicima u školi i učionici. Skoplje: UNICEF, 2018. <https://www. unicef.org/serbia/sites/unicef.org.serbia/files/2018-10/Prirucnik_za_nastavnike. pdf>. 25 12. 2019.

JANJIĆ, Marina. Metodika nastave srpskog kao zavičajnog. Niš: ASA, 2018.

JANJIĆ, Marina. Metodički horizonti-odabrana poglavlja metodike nastave srpskog jezika i književnosti. Beograd: NM libris, 2017.

JOHNSON, David, Roger Johnson. „Effects of cooperative, competitive, and individualistic learning experiences on cross-ethnic interaction and friendships". The Journal of Social Psychology, 118(1) (1982): 47-58.

JOHNSON, David, Roger Johnson, Mary Stanne. Cooperative learning methods: A meta-analysis. Universitety of Minesota, 1/1 (2000). <https://www.researchgate. net/publication/220040324_Cooperative_learning_methods_A_meta-analysis $>$. 25. 12. 2019. 
PAUL, Black, Wiliam Dylan. „Assessment and classroom learning”. Assessment in Education, 5(1), (1998): 7-74.

PETROVIĆ, Danijela, Tijana Jokić. Interkulturalno obrazovanje u srbiji - regulativni okvir, stanje i mogućnosti za razvoj. Beograd: Centar za obrazovne politike, 2016.

VUČO, Julijana, Ljiljana Đurić, Vesna Krajišnik, Nikica Strižak, Mina Suknović, Jelena Filipović. Od srpskog kao stranog jezika do srpskog kao jezika okruženja i obrazovanja: okvir programa jezičke podrške, Beograd: Filološki fakultet, 2018.

\section{Извори}

Pravilnik o standardima kompetencija za profesiju nastavnika i njihovog profesionalnog razvoja, Službeni Glasnik RS - Prosvetni glasnik, br. 5/2011.

Sigurno i podržavajuće osnovnoškolsko okruženje za učenike i učenice izbeglice i tražioce azila (sažetak izveštaja). Beograd: Save the Children za severozapadni Balkan, 2018.

Konvencija o pravima deteta, Beograd: UNICEF, 1989. < file://E:/Downloads/ Konvencija_o_pravima_deteta_sa_fakultativnim_protokolima(1).pdf>

UNHCR Serbia Fact Sheet, September 2017. <file:///E:/Downloads/UNHCR_Serbia September_2017_Fact_Sheet.pdf>

Zakon o osnovama sistema obrazovanja i vaspitanja, Službeni glasnik RS, br. 88/2017.

Marina S. Janjić

\section{ISSUES AND CHALLENGES IN TEACHING OF SERBIAN LANGUGAE AS A LANGUAGE OF EDUCATION AND ENVIRONMENT IN THE SCHOOLS IN THE AREA OF SOUTHERN AND EASTERN SERBIA}

In the schools in the area of southern and eastern Serbia migrant pupils are involved in the teaching of the Serbian language. This presents a great challenge for teachers of the Serbian language, but also for the migrant pupils themselves, too. The paper analyzes the didactic framework of the teaching of Serbian as the language of environment and education, points to the attitudes and opinions of teachers of the Serbian language about working with students asylum seekers, and conclusions are drawn regarding the improvement of the teaching practice of this new linguisticdisciplinary discipline.

Keywords: Serbian language teaching, Serbian as a foreign, Serbian as the language of environment and education. 